\title{
Open-path, quantum cascade-laser-based sensor for high-resolution atmospheric ammonia measurements
}

\author{
D. J. Miller ${ }^{1,2}$, K. Sun ${ }^{1,2}$, L. Tao ${ }^{1,2}$, M. A. Khan ${ }^{1,2, *}$, and M. A. Zondlo ${ }^{1,2}$ \\ ${ }^{1}$ Department of Civil and Environmental Engineering, Princeton University, Princeton, NJ 08540, USA \\ ${ }^{2}$ Center for Mid-Infrared Technologies for Health and the Environment, NSF-ERC, Princeton, NJ, USA \\ *now at: Delaware State University, Dover, DE 19901, USA
}

Correspondence to: M. A. Zondlo (mzondlo@ princeton.edu)

Received: 3 June 2013 - Published in Atmos. Meas. Tech. Discuss.: 31 July 2013

Revised: 30 October 2013 - Accepted: 7 November 2013 - Published: 13 January 2014

\begin{abstract}
We demonstrate a compact, open-path, quantum cascade-laser-based atmospheric ammonia sensor operating at $9.06 \mu \mathrm{m}$ for high-sensitivity, high temporal resolution, ground-based measurements. Atmospheric ammonia $\left(\mathrm{NH}_{3}\right)$ is a gas-phase precursor to fine particulate matter, with implications for air quality and climate change. Currently, $\mathrm{NH}_{3}$ sensing challenges have led to a lack of widespread in situ measurements. Our open-path sensor configuration minimizes sampling artifacts associated with $\mathrm{NH}_{3}$ surface adsorption onto inlet tubing and reduced pressure sampling cells, as well as condensed-phase partitioning ambiguities. Multi-harmonic wavelength modulation spectroscopy allows for selective and sensitive detection of atmospheric pressurebroadened absorption features. An in-line ethylene reference cell provides real-time calibration ( $\pm 20 \%$ accuracy) and normalization for instrument drift under rapidly changing field conditions. The sensor has a sensitivity and noise-equivalent limit $(1 \sigma)$ of $0.15 \mathrm{ppbv} \mathrm{NH}_{3}$ at $10 \mathrm{~Hz}$, a mass of $\sim 5 \mathrm{~kg}$ and consumes $\sim 50 \mathrm{~W}$ of electrical power. The total uncertainty in $\mathrm{NH}_{3}$ measurements is 0.20 ppbv $\mathrm{NH}_{3} \pm 10 \%$, based on a spectroscopic calibration method. Field performance of this open-path $\mathrm{NH}_{3}$ sensor is demonstrated, with $10 \mathrm{~Hz}$ time resolution and a large dynamic response for in situ $\mathrm{NH}_{3}$ measurements. This sensor provides the capabilities for improved in situ gas-phase $\mathrm{NH}_{3}$ sensing relevant for emission source characterization and flux measurements.
\end{abstract}

\section{Introduction}

Atmospheric ammonia $\left(\mathrm{NH}_{3}\right)$, the third most abundant nitrogen species and dominant atmospheric base, is an important precursor to ammoniated fine particulate matter (Nowak et al., 2007; Pinder et al., 2008). Total $\mathrm{NH}_{\mathrm{x}}$, the sum of gasphase $\mathrm{NH}_{3}$ and particulate ammonium $\left(\mathrm{NH}_{4}^{+}\right)$, is an increasingly important component of the reactive nitrogen budget, with implications for human and ecosystem health (Galloway et al., 2003; Pinder et al., 2008; Bobbink et al., 2010). Ammoniated aerosols are a dominant component of inorganic aerosol mass in both clean and urban regions (Jimenez et al., 2009). Gas-phase $\mathrm{NH}_{3}$ measurements are crucial for understanding aerosol nucleation and new particle formation (Ball et al., 1999; Hanson and Eisele, 2002; McMurry et al., 2005; Benson et al., 2011), which facilitate long-range transport of aerosol ammonium and nitrate (Nowak et al., 2007; Pinder et al., 2008). Ammoniated sulfate aerosols also play an important role in cirrus cloud nucleation (Tabazadeh and Toon, 1998; Wang et al., 2008), and aerosol-cloud interactions have significant yet highly uncertain radiative effects on climate (Adams et al., 2001; Martin et al., 2004; Solomon et al., 2007).

Anthropogenic $\mathrm{NH}_{3}$ emissions have more than doubled since preindustrial times, largely due to agricultural livestock and fertilizer emissions (Galloway et al., 2003; Battye et al., 2003; Anderson et al., 2003; Aneja et al., 2008). Uncertainties as large as $50 \%$ exist in global $\mathrm{NH}_{3}$ emission budgets due to the spatial and temporal variability of emissions and a lack of in situ measurements for emission inventory validations (Battye et al., 2003; Clarisse et al., 2009). Recent 
comparisons between measured emissions and concentrations with model inventories found significant discrepancies (Heald et al., 2012; Nowak et al., 2012; Walker et al., 2012).

Gas-phase $\mathrm{NH}_{3}$ has a short atmospheric lifetime of a few hours to a few days, which depends on ambient temperature, relative humidity and aerosol composition (Anderson et al., 2003). High spatial and temporal resolution observations are needed to fully characterize $\mathrm{NH}_{3}$ dynamics, including aerosol nucleation, gas-phase uptake onto particles and volatilization of particulate ammonium (Battye et al., 2003; Nowak et al., 2007; Pinder et al., 2008). In situ $\mathrm{NH}_{3}$ instruments require high (sub-ppbv) sensitivity to measure low atmospheric mole fractions (pptv-ppbv), fast response time and a large dynamic range to capture atmospheric variability (von Bobrutzki et al., 2010). Ammonia sensors must also account for gas-phase $\mathrm{NH}_{3}$ surface adsorption effects and condensed-phase partitioning due to changes in temperature and relative humidity between the sampling volume and ambient atmosphere (Yokelson et al., 2003).

To date, the $\mathrm{NH}_{3}$ measurement challenges have resulted in a variety of different approaches. Conventional offline $\mathrm{NH}_{3}$ sensors (passive filters, denuders and ion chromatography) often have sufficient sensitivity ( $<1 \mathrm{ppbv} \mathrm{NH}_{3}$ ), but have long integration times, lack the requisite selectivity and are labor intensive to analyze (Fehsenfeld et al., 2002; von Bobrutzki et al., 2010; Ellis et al., 2011). Chemical ionization mass spectrometry (CIMS) $\mathrm{NH}_{3}$ instruments have high time resolution (seconds), selectivity and extremely high sensitivity (<100 pptv $\mathrm{NH}_{3}$ ), but require large power consumption (kW) and space (multiple instrument racks) (Nowak et al., 2007; Benson et al., 2010; Sintermann et al., 2011). Laser absorption spectrometers for gas-phase $\mathrm{NH}_{3}$ have been developed for real-time, high-sensitivity and selective detection. Near-infrared diode lasers have been used for $\mathrm{NH}_{3}$ detection, but their sensitivity is limited due to the $\mathrm{NH}_{3}$ overtone bands in the near infrared (Claps et al., 2001; Kosterev and Tittel, 2004).

More recently, advances in room temperature, distributedfeedback quantum cascade (QC) lasers have led to the development of QC-laser-based $\mathrm{NH}_{3}$ sensors using the strongest $\mathrm{NH}_{3}$ absorption transitions located in the mid-infrared spectral region (Manne et al., 2006; Whitehead et al., 2007; McManus et al., 2008; Manne et al., 2009; Curl et al., 2010; Ellis et al., 2010; Gong et al., 2011). Although these closedpath systems are highly sensitive (ppbv or sub-ppbv), they suffer from sampling artifacts that limit precision and response time and complicate calibration methods (Whitehead et al., 2008; von Bobrutzki et al., 2010). In addition, these systems are large (usually $>100 \mathrm{~kg}$ ) and require pumps and temperature control systems with high power consumption (usually hundreds of watts).

In contrast to these closed-path systems, nonintrusive open-path designs address the sampling challenges and provide fast response times (Zondlo et al., 2010; McDermitt et al., 2011; Tao et al., 2012b). Peeters et al. (2000) demonstrated laboratory performance of an open-path cavity-enhanced absorption spectrometer for $\mathrm{NH}_{3}$, but the detection limit was not sufficient for atmospheric measurements. Open-path remote systems employing Fourier transform infrared (FTIR) spectroscopy techniques have been demonstrated for path-integrated field $\mathrm{NH}_{3}$ measurements, including agricultural flux measurements with single ppbv sensitivity (Griffith and Galle, 2000; Galle et al., 2000). Open-path tunable diode laser absorption spectroscopy (TDLAS) and differential optical absorption spectroscopy (DOAS) systems in remote measurement configurations have been used to measure $\mathrm{NH}_{3}$ with ppbv detection limits (Thoma et al., 2005; Volten et al., 2012). Mount et al. (2002) demonstrated open-path $\mathrm{NH}_{3}$ measurements with a mid-ultraviolet DOAS system and achieved 1 ppbv $\mathrm{NH}_{3}$ sensitivity in $1 \mathrm{~s}$. The high time resolution $(>1 \mathrm{~Hz})$ of this approach illustrated the value of an open-path configuration. However, all of these sensors require long paths rather than compact sensor footprints. Currently, there are significant hurdles for compact, open-path, laser-based $\mathrm{NH}_{3}$ sensing, including pressure-broadened absorption lineshapes sensitive to changes in environmental temperature and pressure and interferences from broad, overlapping absorption features from other atmospheric species.

To address the limitations of closed-path techniques and challenges for compact, open-path sensing, we demonstrate the performance of a compact, open-path, high-sensitivity, QC-laser-based atmospheric $\mathrm{NH}_{3}$ sensor. The sensor probes the fundamental mid-infrared $\mathrm{NH}_{3}$ absorption transitions using a QC laser at 9.06 $\mu \mathrm{m}$. Multi-harmonic wavelength modulation spectroscopy is used to isolate overlapping absorption features, and an in-line ethylene reference cell is used for online calibration and normalization to account for sensor drift. The system is relatively compact, low power $(\sim 50 \mathrm{~W})$, and low mass $(\sim 5 \mathrm{~kg})$, with a $10 \mathrm{~Hz}$ time resolution and high sensitivity $(0.30 \mathrm{ppbv}$ minimum detection limit at $10 \mathrm{~Hz})$. The fast response time and dynamic range capabilities of the open-path system are illustrated. In situ $\mathrm{NH}_{3}$ measurements of emission sources are highlighted.

\section{Instrument design}

\subsection{Sensor setup}

The open-path, QC-laser-based $\mathrm{NH}_{3}$ sensor is shown schematically in Fig. 1. Overall, the open-path design is optimized for field portability with a $100 \mathrm{~cm} \times 10 \mathrm{~cm} \times 11 \mathrm{~cm}$ sensor head and a $35 \mathrm{~cm} \times 33 \mathrm{~cm} \times 15 \mathrm{~cm}$ drive electronics unit. The total sensor head mass is $5 \mathrm{~kg}$ including basic shielding (not shown in Fig. 1) to protect components in field conditions. The sensor uses a thermo-electrically (TE) cooled, continuous-wave, single-mode, $9.06 \mu \mathrm{m}$ quantum cascade laser (Alpes Lasers) in a high heat load package, which is detected by a three-stage, TE-cooled, 


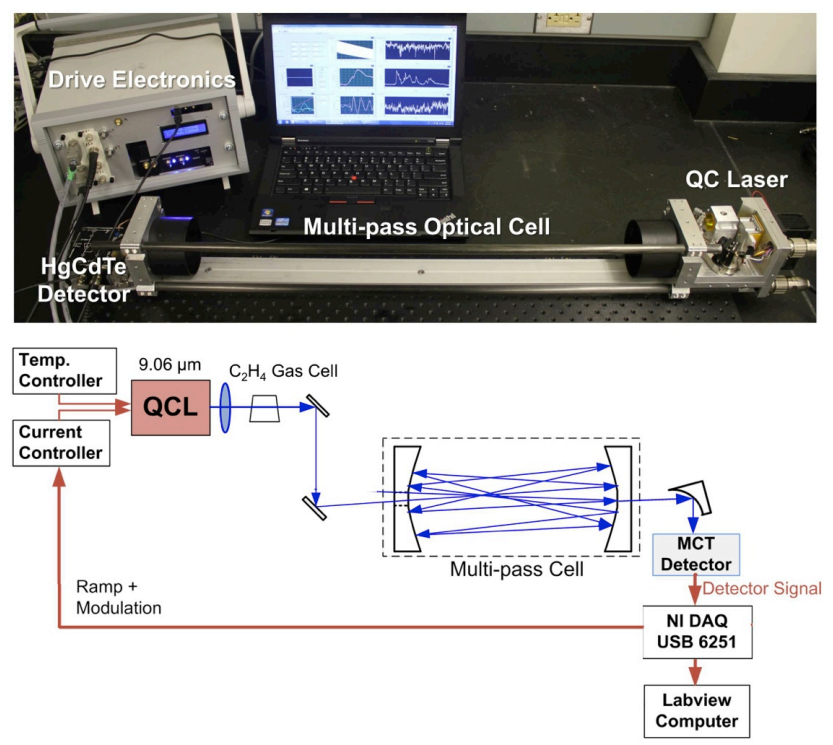

Fig. 1. Open-path atmospheric $\mathrm{NH}_{3}$ sensor with drive electronics (top) and sensor schematic (bottom).

infrared $\mathrm{HgCdTe}$ photodetector (Judson Teledyne). The opto-mechanical design consists of the laser, collimating lens, in-line ethylene reference cell, steering mirrors, multipass optical cell and detector. A Herriott multi-pass cell with spherical mirrors (Herriott et al., 1964) is used to achieve path lengths of $30-60 \mathrm{~m}$ in a $70 \mathrm{~cm}$ base path, depending on the spot pattern implemented. The laser beam is directed into the optical cell consisting of two protected silver-coated, 3inch-diameter spherical mirrors, both with a $6 \mathrm{~mm}$-diameter hole for laser beam entry and exit. We use a configuration with laser and detector components on opposite sides of the optical cell for practical opto-mechanical component design considerations. The QC laser beam size is optimized with focusing mirrors to minimize clipping and distortion effects as the laser beam enters the input hole. A visible alignment laser $(\mathrm{HeNe})$ is used to image the optical spot pattern on the mirrors and couple the QC laser beam into the optical cell. Custom anti-reflection coatings (reflectivity $<0.5 \%$ ) are applied to all transmissive optics, including laser and detector housing windows, to minimize signal baseline artifacts due to interference fringes that are unstable with ambient temperature changes.

The QC laser is driven by a low-noise current driver (Wavelength Electronics, QCL500) and thermally controlled with a precise temperature controller (Wavelength Electronics, HTC3000). The QC laser current is modulated with a sawtooth ramp $(50 \mathrm{~Hz})$ and higher-frequency $(15 \mathrm{kHz})$ sinusoidal modulation. The $\mathrm{QC}$ laser tuning range for $\mathrm{NH}_{3}$ measurements is $0.52 \mathrm{~cm}^{-1}$, based on the current tuning rate at $50 \mathrm{~Hz}$ ramp frequency. Tao et al. (2012a) demonstrated that for the QC laser used here, the current tuning rate decreases with increasing ramp or modulation frequency. Although higher ramp and modulation frequencies should improve sensitivity by minimizing laser excess noise, the decrease in tuning rate at higher frequencies, the broad spectral features probed, and practical QC laser tuning rate limitations prevent us from going to higher frequencies. The tuning rate limitations allow us to achieve a modulation index of $\sim 1.4$ for $\mathrm{NH}_{3}$ measurements, which is not at the most sensitive, optimal value of 2.2 (Reid and Labrie, 1981).

The detector signal is acquired with a National Instruments data acquisition board (NI-USB 6251) and processed in real time. The $50 \mathrm{~Hz}$ raw signal is co-averaged to $2-$ $10 \mathrm{~Hz}$, depending on the field conditions and signal-to-noise ratio (SNR). Multi-harmonic wavelength modulation spectroscopy (WMS) detection is performed with a custom LabVIEW software algorithm, eliminating the need for a benchtop lock-in amplifier, as described in Tao et al. (2012b). The open-path configuration eliminates the need for large pumps that require high power consumption, resulting in significantly lower power consumption $(\sim 50 \mathrm{~W})$ than existing closed-path $\mathrm{NH}_{3}$ sensors. The laptop computer power consumption (currently $\sim 50 \mathrm{~W}$ ) can be reduced further with alternative, lower-power single-board computers or embedded systems. The system requires no cryogenic cooling, allowing for autonomous field operation.

\subsection{Spectroscopy}

The strongest $\mathrm{NH}_{3}$ absorption transitions occur in the midinfrared spectral region near $10.3 \mu \mathrm{m}$ and are probed by other QC laser absorption spectrometers (McManus et al., 2008; Gong et al., 2011). However, this spectral region is not optimal for open-path detection, due to the carbon dioxide $\left(\mathrm{CO}_{2}\right)$ and water vapor $\left(\mathrm{H}_{2} \mathrm{O}\right)$ pressure-broadened absorption lines that overlap with the $\mathrm{NH}_{3}$ absorption lines. The most optimal absorption feature for open-path $\mathrm{NH}_{3}$ detection is at $9.06 \mu \mathrm{m}$, a region between the strong absorption bands of $\mathrm{N}_{2} \mathrm{O}$ below $8.9 \mu \mathrm{m}$ and absorption bands of $\mathrm{CO}_{2}$ and $\mathrm{O}_{3}$ above $9.1 \mu \mathrm{m}$. The selected absorption feature is $\sim 50 \%$ weaker than the stronger $\mathrm{NH}_{3}$ features near $9.5 \mu \mathrm{m}$, but the spectral clarity at $9.06 \mu \mathrm{m}$ allows for higher sensitivity. Figure $2 \mathrm{a}$ shows spectra simulated using the HIgh-resolution TRANsmission Molecular Absorption database (HITRAN) in the $9.06 \mu \mathrm{m}$ region for $1 \mathrm{ppbv} \mathrm{NH}_{3}$ and typical ambient mixing ratios of atmospheric absorbers at $296 \mathrm{~K}$ and $1013.25 \mathrm{hPa}$ for a $60 \mathrm{~m} \mathrm{op}$ tical path length. The $\mathrm{NH}_{3}$ absorption feature at $9.06 \mu \mathrm{m}$ in Fig. 2a is a superposition of six overlapping absorption transitions. This feature overlaps with the minimum of a neighboring $\mathrm{H}_{2} \mathrm{O}$ absorption feature, producing a direct absorption baseline. Owen et al. (2013) performed spectroscopic studies on relevant atmospheric absorbers in this region at reduced pressure to characterize the interferences. For openpath detection at ambient pressures, wavelength modulation spectroscopy is a well-suited detection technique for spectral resolution of these weak, overlapping absorption features (Schilt et al., 2003; Zondlo et al., 2010). As shown in Fig. 2b, 
(a)

(b)
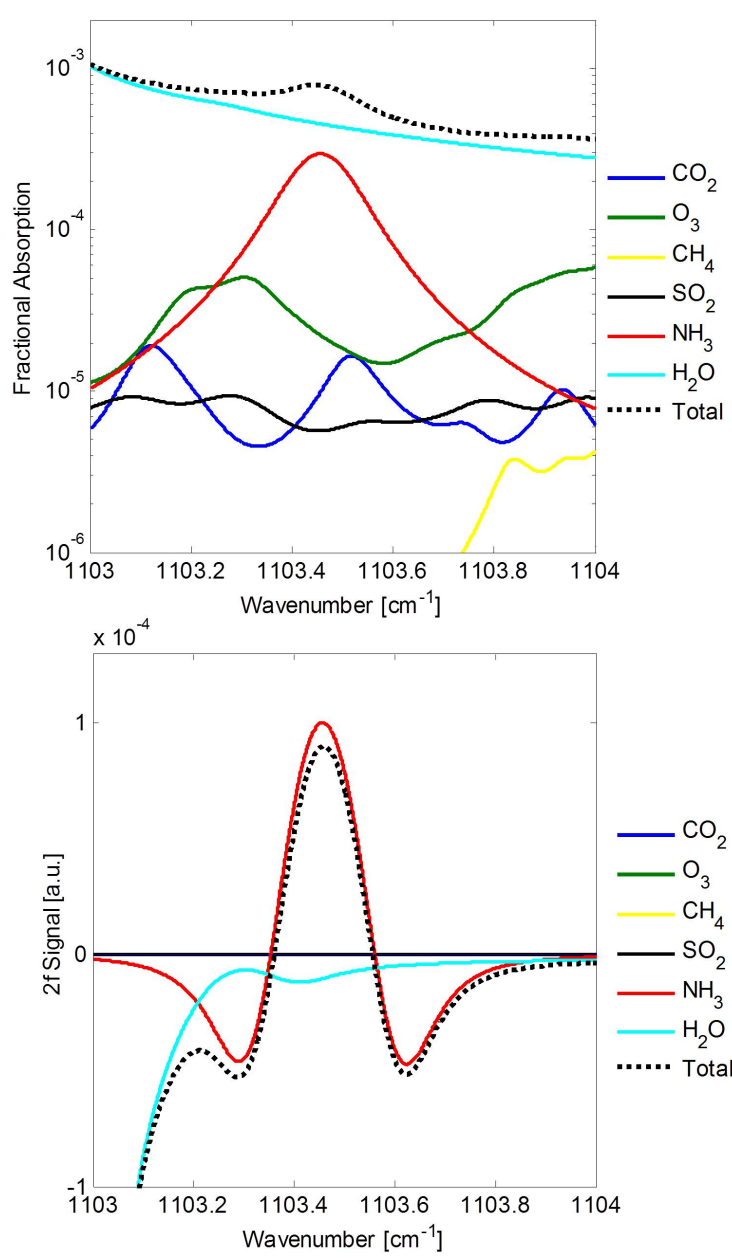

Fig. 2. (a) Direct absorption HITRAN simulation (Rothman et al., 2009) calculated based on $60 \mathrm{~m}$ path length, $296 \mathrm{~K}, 1013.25 \mathrm{hPa}$ and the following atmospheric mixing ratios: $400 \mathrm{ppmv} \mathrm{CO}_{2}, 80 \mathrm{ppbv}$ $\mathrm{O}_{3}, 1800 \mathrm{ppbv} \mathrm{CH}_{4}, 5 \mathrm{ppbv} \mathrm{SO}_{2}, 1 \mathrm{ppbv} \mathrm{NH}_{3}$ and $2 \% \mathrm{H}_{2} \mathrm{O}$; (b) second harmonic spectrum calculated with same species showing reduction of the water vapor baseline. Ozone and $\mathrm{CH}_{4}$ do not appear in the second harmonic spectrum as they are flat baselines. The black dotted lines in (a) and (b) denote the total absorption of all species simulated.

second harmonic (2f) detection minimizes the water vapor absorption baseline and improves sensitivity and selectivity (Reid and Labrie, 1981). Other atmospheric species such as $\mathrm{CO}_{2}, \mathrm{O}_{3}$ and $\mathrm{SO}_{2}$ also absorb in this region below $\sim 5 \times 10^{-5}$ fractional absorption. We note that polluted conditions are illustrated in Fig. 2 (5 ppbv $\mathrm{SO}_{2}$ and 80 ppbv $\mathrm{O}_{3}$ ) to represent ambient conditions with possible interferences. However, the $\mathrm{NH}_{3}$ absorption at $9.06 \mu \mathrm{m}$ for $1 \mathrm{ppbv} \mathrm{NH}_{3}$ is greater than five times the absorption of these species in this spectral region. Overall, the only significant interfering species for $2 \mathrm{f}$ detection at $9.06 \mu \mathrm{m}$ is $\mathrm{H}_{2} \mathrm{O}$, which is addressed in the following section. The $\mathrm{O}_{3}$ absorption baseline begins to interfere significantly for $\mathrm{NH}_{3}$ mole fractions below $100 \mathrm{pptv}$.

\subsection{Ammonia mole fraction retrieval}

The ammonia mole fraction is retrieved with real-time spectral fitting at $10 \mathrm{~Hz}$. We simulate the direct absorption signal recorded by the detector with multiple Voigt lineshape profiles for all relevant absorption transitions within the laser scan range as follows:

$D=\chi \cdot I(t) \cdot \exp \left(-\sum_{i}\left(x_{i} S_{i} L_{i} \psi_{i}(T, P, v(t))\right)\right.$,

where $\chi$ is the detector collection efficiency; $I(t)$ is the laser intensity function; $x_{i}, S_{i}$ and $L_{i}$ are the number density, absorption line strength and path length, respectively, for different absorbing species $i$; and $\psi_{i}(T, P, v(t))$ is the Voigt lineshape function for absorption feature $i$, a function of temperature, pressure and wavenumber $v(t)$. This signal is multiplied by a reference signal at the $n$th harmonic and passed through a virtual lock-in amplifier based on a numerical wavelength modulation spectroscopy model (Tao et al., $2012 b)$. A least-squares fitting routine is implemented to produce fitting coefficients for mole fraction, DC signal offset, linear and second-order polynomial baselines. The secondorder polynomial baseline fitting accounts for baseline effects, including detector nonlinearity, intensity modulation and interference fringing. The spectroscopic parameters used in the fitting routine for the $\mathrm{NH}_{3}$ absorption lines of interest have been measured experimentally by Sun et al. (2013), and generally agree to within $10 \%$ of HITRAN. Ambient temperature and pressure are measured with a digital temperature sensor (HYT $271, \pm 0.2^{\circ} \mathrm{C}$ accuracy) and digital pressure sensor (MS5803-01BA, $\pm 0.5 \mathrm{hPa}$ accuracy) at $1 \mathrm{~Hz}$ and updated in real time for the fitting routine. An in-line ethylene reference cell is inserted into the optical path as explained below.

Water vapor introduces multiple, minor potential interferences for the $2 \mathrm{f} \mathrm{NH}_{3}$ retrieval. The average ambient $\mathrm{H}_{2} \mathrm{O}$ mixing ratio for a given region and time period of sensor field deployment is used for spectral fitting of the $\mathrm{H}_{2} \mathrm{O}$ absorption baseline and used to calculate absorption line widths to account for $\mathrm{H}_{2} \mathrm{O}$ broadening using the coefficients measured by Owen et al. (2013). On short timescales, the variability of ambient $\mathrm{H}_{2} \mathrm{O}$ vapor (a few hundred ppmv) has a negligible ( $<0.5 \%$ impact on the $2 \mathrm{f} \mathrm{NH}_{3}$ retrieval. For larger changes of water vapor, the $\mathrm{H}_{2} \mathrm{O}$ mixing ratio is updated in the spectral fit using routine meteorological data.

The $\mathrm{NH}_{3}$ and ethylene absorption features (centered at $1103.46 \mathrm{~cm}^{-1}$ and $1103.36 \mathrm{~cm}^{-1}$, respectively) are fit simultaneously both in second (2f) and eighth (8f) harmonics. The multi-harmonic approach separates the overlapping, broad ambient $\mathrm{NH}_{3}$ absorption feature from the narrower ethylene reference signal as demonstrated by Sun et al. (2013). Figure 3 shows representative $2 \mathrm{f}$ and $8 \mathrm{f}$ spectra along with fitting results and residuals for a $19.0 \mathrm{ppbv}$ ambient $\mathrm{NH}_{3}$ signal. The $2 \mathrm{f}$ signal has two extra troughs, indicated by arrows, due to the ethylene absorption overlapped with the ambient 

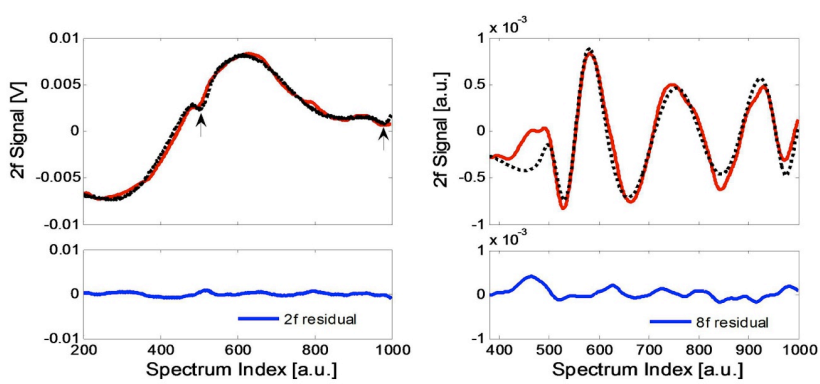

Fig. 3. Ammonia $2 \mathrm{f}$ (left) and ethylene $8 \mathrm{f}$ (right) spectra recorded at $10 \mathrm{~Hz}$ with real-time fitting results (dotted lines) and residuals. The $2 \mathrm{f} \mathrm{NH}_{3}$ signal was recorded for ambient laboratory conditions of $19.0 \mathrm{ppbv} \mathrm{NH}_{3}$. The two arrows in the $2 \mathrm{f}$ plot denote the locations of the two extra troughs due to the ethylene reference signal.

$\mathrm{NH}_{3}$ signal. The eighth harmonic (8f) is used for ethylene reference signal detection to achieve optimal separation between ambient $\mathrm{NH}_{3}$ and ethylene reference signals. The $8 \mathrm{f}$ signal isolates the relatively narrow, reduced pressure ethylene reference signal, with negligible influence from ambient $\mathrm{NH}_{3}$ absorption at $8 \mathrm{f}$. We do not use harmonic orders higher than $8 \mathrm{f}$ due to limits of signal-to-noise ratio, since the signal intensity decreases as harmonic order increases. The even harmonic orders are advantageous since the maximum of the WMS function occurs at the spectral line center, which is useful for line-locking procedures.

\subsection{Calibration methods}

We implement an online spectroscopic calibration method using ethylene, which exhibits negligible adsorption artifacts compared with $\mathrm{NH}_{3}$. We do not use an $\mathrm{NH}_{3}$ reference calibration cell due to adsorption artifacts associated with changes in cell temperature and pressure. In addition, when ambient and reference absorption features of the same species are overlapping, separating changes in mole fraction from changes in the reference signal becomes difficult. The in-line ethylene reference cell contains $1.5 \%$ ethylene in nitrogen at $50 \mathrm{hPa}$ total pressure in a $3 \mathrm{~cm}$ length. The ethylene mixing ratio was chosen to be comparable to $\mathrm{NH}_{3}$ signals at ppbv levels. Spectroscopic parameters of both $\mathrm{NH}_{3}$ and ethylene absorption features have been measured and compared with the HITRAN database to evaluate the calibration accuracy. Sun et al. (2013) has demonstrated this ethylene signal can serve as a reference of $\mathrm{NH}_{3}$ mole fraction in real time, with an overall calibration accuracy of $\pm 20 \%$.

We also perform offline absolute calibration using $\mathrm{NH}_{3}$ direct absorption measurements. Prior verification of path length was performed and uncertainties in the HITRAN parameters for these $\mathrm{NH}_{3}$ absorption lines were previously characterized (Sun et al., 2013). Owen et al. (2013) also studied these absorption transitions and reported lineshape parameter uncertainties of $<10 \%$. The standard $\mathrm{NH}_{3}$ mole fractions for calibration of our WMS retrieval are calculated based on a direct absorption fitting using these calibrated HITRAN parameters. The absolute accuracy of this offline calibration method $( \pm 10 \%)$ is comparable to current high-sensitivity, state-of-the-art $\mathrm{NH}_{3}$ sensors. For example, the pulsed QC-laser-based $\mathrm{NH}_{3}$ instrument demonstrated by McManus et al. (2008) has a typical concentration uncertainty of 5-20\%. Nowak et al. (2007) found uncertainties in CIMS $\mathrm{NH}_{3}$ measurements to be $\pm 25-30 \%$ during field operation. Sintermann et al. (2011) found calibration accuracy of $\sim 5 \%$ for a CIMS $\mathrm{NH}_{3}$ instrument.

In addition to calibration, the in-line ethylene reference signal is especially advantageous as it provides normalization for sources of instrument drift. Normalization for sensor drift is essential for open-path systems exposed directly to changing environmental conditions, which lead to undesirable or unknown opto-mechanical and electronic responses such as optical interference fringes, electrical component drift, laser and detector instabilities and light attenuation due to precipitation. In addition, the sharp peaks and troughs of the $8 \mathrm{f}$ signal are used for line-locking via laser current adjustment to account for thermal drifts of the laser wavelength. This improves the drift during a typical $\sim 10^{\circ} \mathrm{C}$ diurnal ambient temperature cycle from $0.04 \mathrm{~cm}^{-1}$ to $<0.005 \mathrm{~cm}^{-1}$.

\section{Instrument performance}

\subsection{Calibration}

We perform absolute calibration offline using direct absorption spectroscopy as a reference method to measure $\mathrm{NH}_{3}$ mole fraction independent of our WMS $\mathrm{NH}_{3}$ retrieval based on $2 \mathrm{f}$ detection. The open-path optical cell is enclosed in a polyethylene calibration tube, into which a flow of $25 \mathrm{ppmv}$ $\mathrm{NH}_{3}$ in $\mathrm{N}_{2}$ is introduced. This $25 \mathrm{ppmv} \mathrm{NH}_{3}$ standard mixing ratio is decreased incrementally by dilution with dry air and each calibration point is recorded in both $2 \mathrm{f}$ and direct absorption as shown in Fig. 4. The horizontal axis is the $\mathrm{NH}_{3}$ standard mole fraction derived from direct absorption measurements. The vertical axis displays the retrieved $\mathrm{NH}_{3}$ mole fraction based on $2 \mathrm{f}$ spectral fitting with the online spectroscopic calibration method described in Sect. 2.3. We note that the calibration is performed at mole fractions much less than that of the original $25 \mathrm{ppmv} \mathrm{NH}_{3}$ standard. Therefore, we use HITRAN parameters appropriate for $\mathrm{NH}_{3}$ in dry air. The mole fraction retrieval is derived from nonlinear Voigt lineshape fitting of the direct absorption spectra along with measured ambient temperature and pressure, and assumes the mole fraction is linearly proportional to the fractional absorption for typical (ppbv) atmospheric $\mathrm{NH}_{3}$ mole fractions. However, the retrieved mole fraction does not scale linearly with the standard mole fraction due to strong absorption nonlinearity at mole fractions $>100 \mathrm{ppbv} \mathrm{NH}_{3}$. Therefore, we fit a third-order polynomial to calibrate the retrieved mole fraction as shown in Fig. 4. The linearity of retrieved mole 


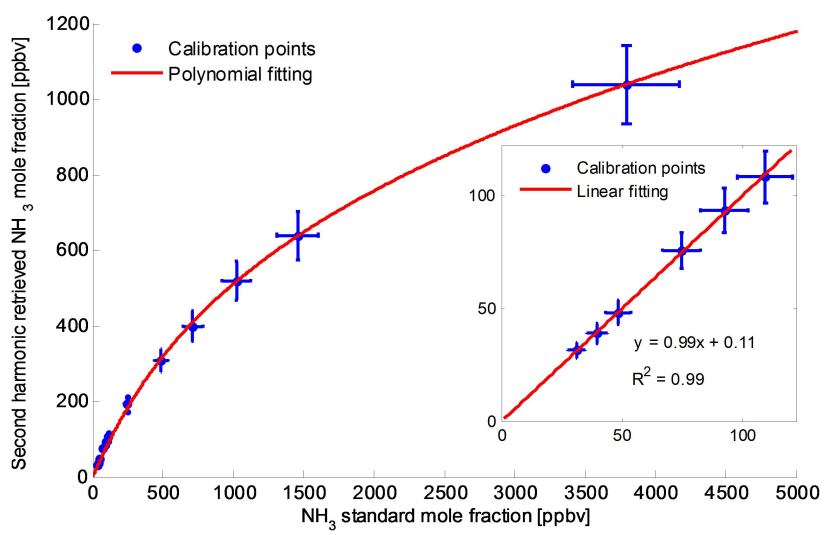

Fig. 4. Calibration curve derived from direct absorption measurements for various $\mathrm{NH}_{3}$ gas standard mole fractions at atmospheric pressure. Inset: linear fitting of calibration curve for mole fractions below $120 \mathrm{ppbv} \mathrm{NH}_{3}$. Error bars for each calibration point are $\pm 10 \%$ for each measurement method (direct absorption and $2 \mathrm{f}$ retrieval).

fraction is shown in the inset plot of Fig. 4 for mole fractions below $\sim 120 \mathrm{ppbv} \mathrm{NH}_{3}$. In this regime, we can assume absorption is linear with number concentration (and mole fraction assuming constant temperature and pressure) based on the Beer-Lambert law weak absorption limit. A linear bestfit line in this range yields $R^{2}=0.99$, in agreement with the weak absorption limit. The surface adsorption and partitioning artifacts associated with $\mathrm{NH}_{3}$ calibrations present unique challenges which limit accuracy, especially for low ambient mole fractions. Our accuracy is constrained by the uncertainty in the HITRAN parameters for the $\mathrm{NH}_{3}$ absorption features, which is estimated to be $\sim 10 \%$ (Sun et al., 2013).

Calibration of the zero $\mathrm{NH}_{3}$ baseline offset is also important when retrieving $\mathrm{NH}_{3}$ mole fractions near the detection limit. The zero calibration point is obtained by flushing the calibration tube with dry air and coating the calibration tube surfaces with a concentrated $(\sim 20 \mathrm{wt} \%)$ citric acid solution to minimize $\mathrm{NH}_{3}$ desorption effects. We note that true zero $\mathrm{NH}_{3}$ conditions are very difficult to achieve for any $\mathrm{NH}_{3}$ instrument, due to surface adsorption and partitioning artifacts as well as residual $\mathrm{NH}_{3}$ found in dry air. We perform zero calibrations prior to, during, and following field deployments, along with the full calibration procedure described in Sect. 2.4. Based on these zero calibrations, our absolute uncertainty in the zero calibration is $0.20 \mathrm{ppbv} \mathrm{NH}_{3}$. It is important to note that each time zero calibration is performed, there is additional uncertainty due to differences in the amount of residual $\mathrm{NH}_{3}$ in the calibration tube. Thus, $0.20 \mathrm{ppbv}$ is an upper limit to our estimate of the zero calibration uncertainty. This metric defines an absolute accuracy at low $\mathrm{NH}_{3}$ mole fractions, due to uncertainty in the zero calibration point. Thus, the total estimated uncertainty is $0.20 \mathrm{ppbv}$ $\mathrm{NH}_{3} \pm 10 \%$.
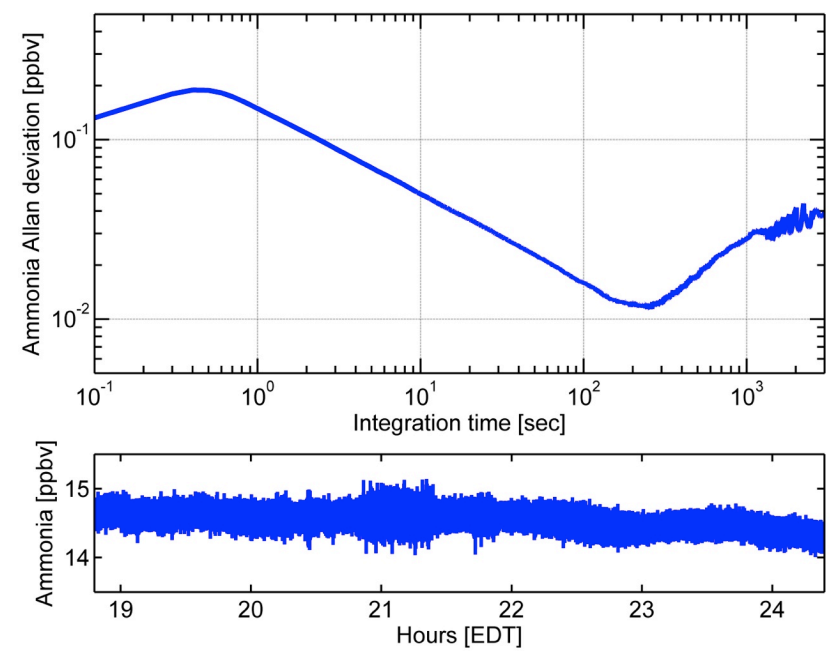

Fig. 5. Allan deviation plot of $14.6 \mathrm{ppbv} \mathrm{NH}_{3}$ and the associated time series data recorded at $10 \mathrm{~Hz}$ over the course of $5.5 \mathrm{~h}$.

\subsection{Precision}

To investigate precision and stability of the open-path $\mathrm{NH}_{3}$ sensor, Allan deviation analyses (Werle et al., 1993) are performed on $\mathrm{NH}_{3}$ and ethylene reference signal time series. We compare the drift characteristics of the ambient and reference signals to determine the optimal integration time for normalization by the ethylene reference signal. For this analysis, we normalize both $\mathrm{NH}_{3}$ and ethylene retrievals by the $1 \mathrm{f} \mathrm{DC}$ value to account for changes in light intensity on the detector. The $\mathrm{NH}_{3}$ mole fraction and air temperature are variable in the laboratory during the recorded time series, whereas the ethylene mixing ratio in the reference cell is essentially constant.

Figure 5 shows the Allan deviation plot for $\mathrm{NH}_{3}$ measurements, with a mean mixing ratio of $14.6 \mathrm{ppbv} \mathrm{NH}_{3}$ recorded in the laboratory at $10 \mathrm{~Hz}$ time resolution. The precision is $\sim 1 \%$, or $0.15 \mathrm{ppbv} \mathrm{NH}_{3}$, at $10 \mathrm{~Hz}$. The precision is similar at $1 \mathrm{~Hz}$ integration time. The minimum precision is $\sim 15 \mathrm{pptv}$ $\mathrm{NH}_{3}$ for an integration time of $\sim 200 \mathrm{~s}$, beyond which drift dominates the Allan deviation. The $10 \mathrm{~Hz}$ precision is maintained out to timescales greater than $1 \mathrm{~h}$. We note that while the $2 \mathrm{f} \mathrm{NH}_{3}$ signal is fit in real time at $10 \mathrm{~Hz}$, the data acquisition is synchronized by the $1 \mathrm{~Hz}$ GPS pulse-per-second signal and the current linelocking scheme also at $1 \mathrm{~Hz}$, which results in a transition from $100 \%$ to an effective $10 \%$ duty cycle from $0.1 \mathrm{~s}$ to $1 \mathrm{~s}$ integration time. We also note that the corresponding offset is consistent with a $\sqrt{ } 10$ decrease in $\mathrm{Al}-$ lan deviation resulting from a $10 \%$ duty cycle (Werle et al., 1993) at $1 \mathrm{~Hz}$ and longer timescales.

The Allan deviation plot for the ethylene reference signal recorded at $1 \mathrm{~Hz}$ time resolution is shown in Fig. 6. Ethylene signals are co-averaged to $1 \mathrm{~Hz}$ time resolution to improve the signal-to-noise ratio at the higher $(8 \mathrm{f})$ harmonics. The precision of the ethylene signal is $\sim 1 \%$ at $1 \mathrm{~Hz}$, comparable 

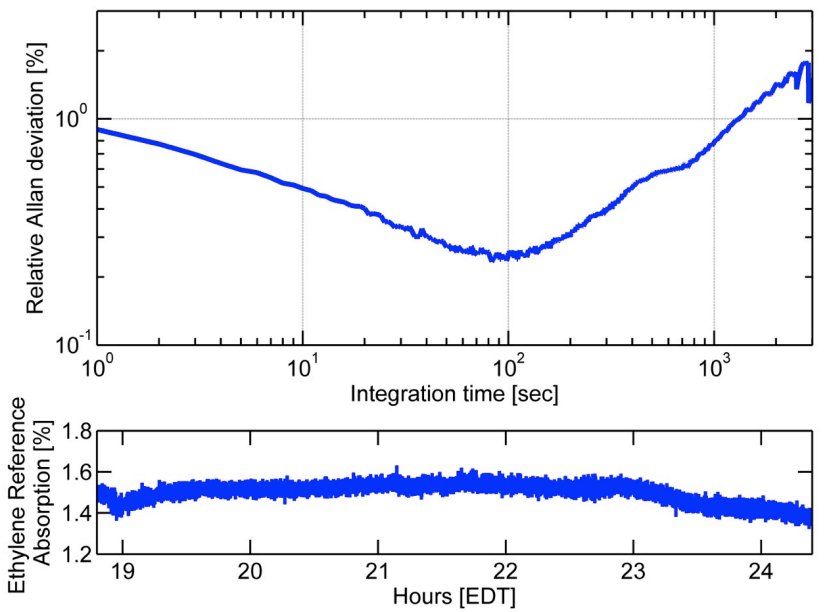

Fig. 6. Allan deviation plot of in-line ethylene reference cell signal and associated $5.5 \mathrm{~h}$ time series. The Allan deviation is expressed as a percent of the mean value of the reference signal time series (relative Allan deviation). Ethylene is recorded at $1 \mathrm{~Hz}$ time resolution.

to that for $\mathrm{NH}_{3}$. The precision improves as integration time increases, but interference fringing at the higher harmonics (8f) and laser thermal drift limit this improvement for integration times $>100 \mathrm{~s}$. The minimum of the $\mathrm{NH}_{3}$ Allan deviation in Fig. 6 occurs at an integration time of $\sim 200$ s. Thus, a $200 \mathrm{~s}$ integration time is optimal for normalization by the ethylene reference signal to account for drift in the $\mathrm{NH}_{3}$ signal. Note that the data in Figs. 5 and 6 show drift of $\sim 1 \%$ or less at $3000 \mathrm{~s}$ integration time, which is much lower than the overall accuracy $( \pm 10 \%)$. In this case, the in-line ethylene reference signal is of marginal value under relatively constant laboratory conditions. However, the in-line ethylene signal is an important method to account for much larger system drifts expected under rapidly changing field conditions and over longer timescales (days).

\subsection{Minimum detection limit}

The minimum detection limit of the $\mathrm{NH}_{3}$ sensor was determined by the measuring $2 \sigma$ of the background zero ammonia signal time series. The short-term noise is expected to be the limiting factor for the minimum detection limit, as the Allan deviation plot shown in Fig. 5 indicates precision better than the $10 \mathrm{~Hz}$ precision on long timescales.

We analyze the spectral fitting at $1 \mathrm{ppbv} \mathrm{NH}_{3}$ mole fraction with baseline subtraction to estimate the spectral noise levels. Figure $7 \mathrm{a}$ shows a $1.0 \mathrm{ppbv} \mathrm{NH}_{3}$ signal with spectral fitting and residuals. Figure $7 \mathrm{~b}$ illustrates the base functions for the full spectral fit in Fig. 7a, with contributions from $\mathrm{NH}_{3}$, ethylene and the polynomial baseline. Based on the height of the baseline-subtracted $2 \mathrm{f} \mathrm{NH}_{3}$ signal and the residuals of the fit to this baseline-subtracted signal, the SNR for this spectrum is $\sim 7.6$, corresponding to a spectral noise level $(2 \sigma)$ of $0.26 \mathrm{ppbv} \mathrm{NH}_{3}$ at $1 \mathrm{~Hz}$. The interference due to $\mathrm{O}_{3}$ and

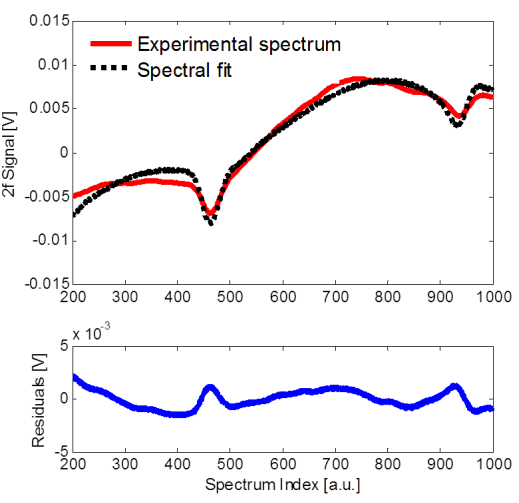

(a)
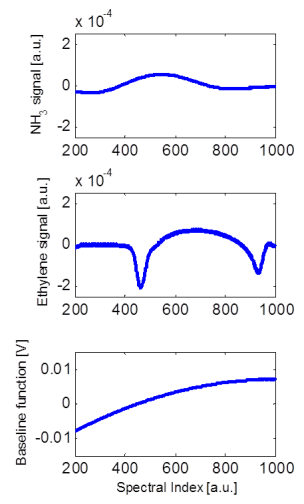

(b)

Fig. 7. (a) Second harmonic spectrum of $1.0 \mathrm{ppbv} \mathrm{NH}_{3}$ signal at ambient pressure recorded at $1 \mathrm{~Hz}$ along with spectral fitting results and residuals. (b) Base functions used in spectral fitting in (a) as follows: $2 \mathrm{f} \mathrm{NH}_{3}$ lineshape (top), $2 \mathrm{f}$ ethylene lineshape (middle) and polynomial baseline (bottom).

$\mathrm{CO}_{2}$ absorption lines is $\sim 20 \%$ of the 1 ppbv $\mathrm{NH}_{3}$ signal (see Sect. 2.2), which is smaller than the baseline spectral noise $(\sim 26 \%)$. We note that this estimate is derived from only one spectrum and may not be representative of the temporal variability of the background noise, which is expected to be dominated by optical interference fringing and electronic noise.

Background concentrations are difficult to determine for $\mathrm{NH}_{3}$ in an open-path configuration, in large part due to the need to enclose the sensor, leading to adsorption and desorption effects with typical laboratory mole fractions greater than 10 ppbv $\mathrm{NH}_{3}$. To achieve a zero $\mathrm{NH}_{3}$ background signal and examine the time series characteristics of the noise and spectral fitting, we conducted additional experiments inside a pressure-regulated chamber. The calibration tube and the entire sensor head were placed inside a larger chamber with its inside walls coated with the citric acid solution. The larger chamber was pumped to a reduced pressure of $100 \mathrm{hPa}$. Even though the sensor was at $100 \mathrm{hPa}$, we maintained the same modulation amplitude as at ambient pressures. The absorption features of $\mathrm{NH}_{3}$ and other relevant species are therefore overmodulated (effective modulation index $>5$ for $\mathrm{NH}_{3}$ at $100 \mathrm{hPa}$ ), effectively broadening and decreasing the $2 \mathrm{f}$ signal height by $67 \%$ compared to ambient pressures. The overmodulated $2 \mathrm{f} \mathrm{NH}_{3}$ signal is used to calculate the background noise, since it minimizes the influences of residual $\mathrm{NH}_{3}$ on the $2 \mathrm{f}$ signal. We also verified that there was negligible residual $\mathrm{NH}_{3}$ in the chamber by switching to lower modulation amplitude appropriate for $100 \mathrm{hPa}$. Figure 8 shows the $2 \mathrm{f}$ spectrum recorded at $100 \mathrm{hPa}$ under these conditions, which is effectively representative of etalon and electrical noise. It is assumed here that etalons, determined by the free spectral range of various transmissive optics, are not affected by pressure changes since the whole sensing system is enclosed inside the chamber. We fit the background signals to 


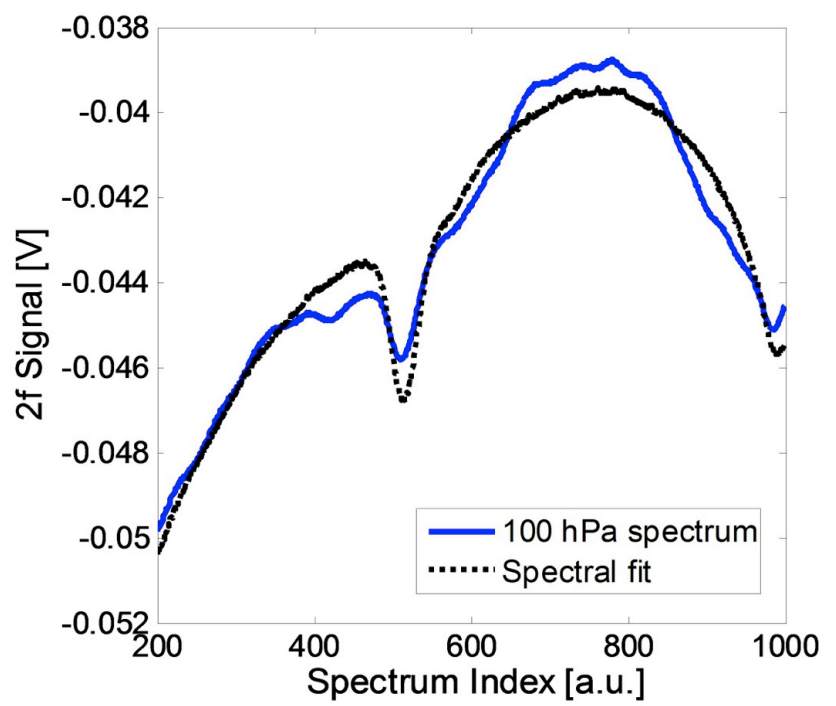

Fig. 8. Second harmonic spectrum at reduced pressure $(100 \mathrm{hPa})$ with zero $\mathrm{NH}_{3}$ signal recorded at $10 \mathrm{~Hz}$ time resolution.

the ambient pressure lineshape function to examine how the spectral fit to the background (which should nominally be zero) changes over time. The noise-equivalent limit, defined as $1 \sigma$ of the background signal time series, is $0.15 \mathrm{ppbv} \mathrm{NH}_{3}$ at $10 \mathrm{~Hz}$ and the minimum detection limit $(2 \sigma)$ is $0.30 \mathrm{ppbv}$ $\mathrm{NH}_{3}$ at $10 \mathrm{~Hz}$. This detection limit is also consistent with the measurement precision shown in Sect. 3.2 and the spectral noise analysis described above.

We note that other potential methods to achieve background measurements have limitations for our system. One approach would be tuning the laser to a different wavelength region. However, the QC laser used here has a limited tuning range and this method will produce a different baseline due to changes in laser optical power, detector response and interference fringing. In addition, there are other absorbing species (e.g., $\mathrm{H}_{2} \mathrm{O}, \mathrm{CO}_{2}, \mathrm{O}_{3}, \mathrm{SO}_{2}$ ) that will contribute to the spectroscopic baseline on either side of the $\mathrm{NH}_{3}$ spectral feature of interest.

\subsection{Open-path time response}

We demonstrate the dynamic response of the open-path configuration. Figure 9 shows the time series of $\mathrm{NH}_{3}$ mixing ratios measured in the field on a mobile vehicular platform at a dairy farm over the course of $\sim 3 \mathrm{~min}$ at $5 \mathrm{~Hz}$ time resolution. During this time series, an order-of-magnitude decrease in mixing ratio from $\sim 2.0 \mathrm{ppmv} \mathrm{NH}_{3}$ to $200 \mathrm{ppbv} \mathrm{NH}_{3}$ is observed within $1 \mathrm{~s}$. The inset plot of Fig. 9 shows a $5 \mathrm{~s}$ portion of this time series on a logarithmic $y$ scale to emphasize the two-order-of-magnitude change in mixing ratio. During this time period, the sensor records an increase from $\sim 200$ to $\sim 900$ ppbv $\mathrm{NH}_{3}$ in $1 \mathrm{~s}$ followed by a decrease in mixing ratio $\left(\sim 900\right.$ to $\left.\sim 200 \mathrm{ppbv} \mathrm{NH}_{3}\right)$ in $0.8 \mathrm{~s}$. The mixing ratio

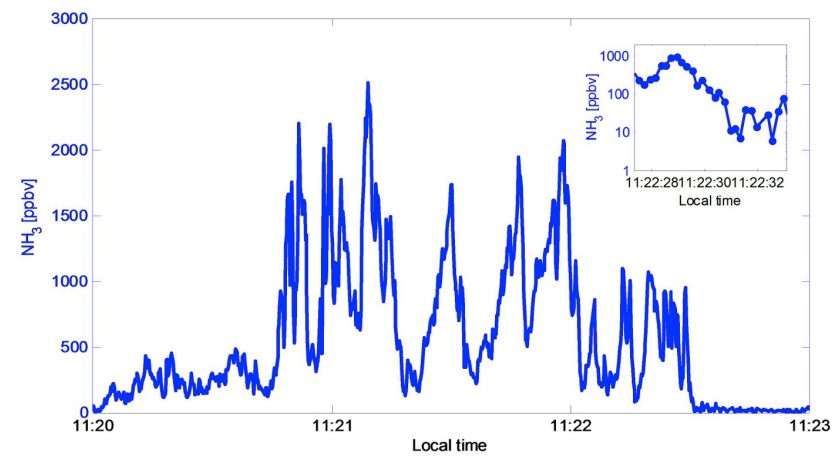

Fig. 9. Mobile, open-path $\mathrm{NH}_{3}$ measurements of in situ dairy farm sources recorded at $5 \mathrm{~Hz}$. The inset plot shows a $5 \mathrm{~s}$ portion of this $5 \mathrm{~Hz}$ time series on a logarithmic $y$ scale to emphasize the twoorder-of-magnitude change in $\mathrm{NH}_{3}$ mixing ratios.

decreases by two orders of magnitude to background levels $\left(\sim 10 \mathrm{ppbv} \mathrm{NH}_{3}\right)$ within $2 \mathrm{~s}$ following the ppmv maximum as the sensor left the farm and was no longer sampling the emission plume. This demonstrates the fast response time of the open-path sensor for two-order-of-magnitude changes in mixing ratio in a very short $(2 \mathrm{~s})$ time period.

We also demonstrate the time response for smaller mixing ratio enhancements. Figure 10 shows a time series of mobile measurements on the highway recorded at $2 \mathrm{~Hz}$ time resolution. There are two enhancements observed due to vehicle traffic emissions on the highway. For the first spike at 15:45:40 local time, the sensor recorded an increase of 10 ppbv $\mathrm{NH}_{3}$ (13.0 to $23.0 \mathrm{ppbv}$ ) in $1 \mathrm{~s}$. For the second maximum at 15:49:30 local time, the decrease in mixing ratio from 16.0 to $10.0 \mathrm{ppbv}$ following the transient spike is also recorded in $1 \mathrm{~s}$. These measurements demonstrate similar fast response for a lower range of mixing ratios.

Ammonia surface adsorption and desorption effects in closed-path sensors typically limit the response time (for several hundred ppbv $\mathrm{NH}_{3}$ changes) to a few seconds, resulting in attenuation of high-frequency concentration fluctuations (Yokelson et al., 2003; Nowak et al., 2007; McManus et al., 2008; Whitehead et al., 2008; Ellis et al., 2010; Gong et al., 2011). The time response of closed-path sensors is often defined by the initial time constant for gas exchange and the slower surface adsorption time constant (e.g., $\sim 0.4 \mathrm{~s}$ and $\sim 15 \mathrm{~s}$, respectively, for a QC-TDLAS instrument) (Ellis et al., 2010). For long-term stationary monitoring applications, this time response is sufficient since data are averaged to minutes or longer timescales. However, for mobile platform measurements of transient emissions with order-ofmagnitude changes in mixing ratios, as well as eddy covariance flux measurements, a time response of at least $1 \mathrm{~Hz}$, as demonstrated for this open-path sensor, is critical. 


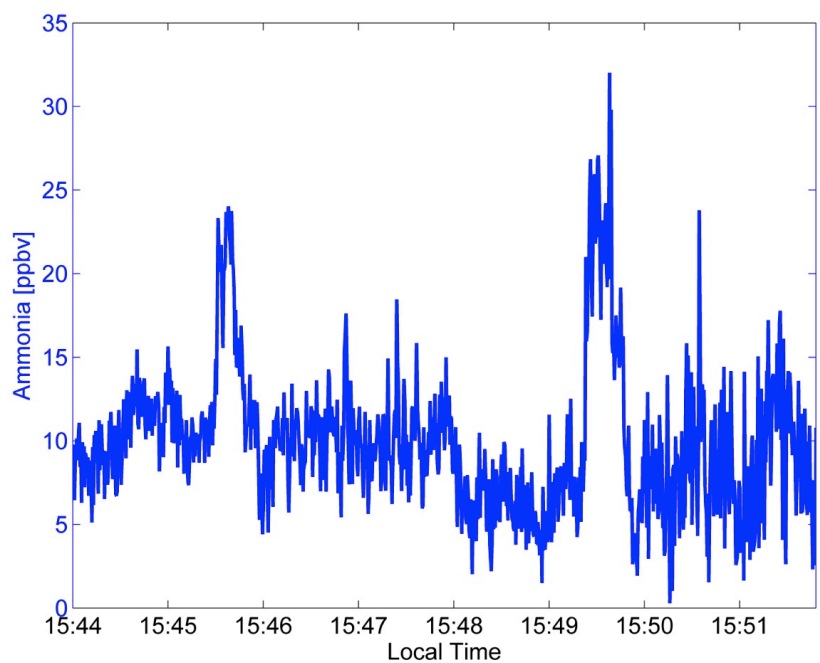

Fig. 10. On-road, mobile, open-path $\mathrm{NH}_{3}$ measurements of highway vehicle emissions recorded at $2 \mathrm{~Hz}$. The response time at ppbv $\mathrm{NH}_{3}$ mixing ratios is demonstrated for the emission spikes at 15:45:40 and 15:49:30 local time.

\section{Field measurements}

The open-path $\mathrm{NH}_{3}$ sensor has been field deployed in a wide range of environments with autonomous operation on daily timescales. These include hot, dusty, and dry conditions in the San Joaquin Valley, California; $>40^{\circ} \mathrm{C}$ ambient temperatures and high humidity (mid $-20^{\circ} \mathrm{C}$ dew points) in Princeton, New Jersey; and cold, rain and dew conditions in Baltimore and Beltsville, Maryland (Miller et al., 2012). The sensor has also operated on a mobile, battery-powered vehicular platform for $>7000 \mathrm{~km}$, in which ambient air flows across the optical cell region as the vehicle moves and the sensor platform is exposed to vibrations. These field deployments led to improvements in the opto-mechanical design to address temperature cycling effects on the alignment, laser thermal stability and detector temperature control (Miller et al., 2012). The optical cell structure and mirror mounting were custom designed with carbon fiber rods to minimize temperature cycling effects.

We performed high time resolution $(5 \mathrm{~Hz})$ open-path $\mathrm{NH}_{3}$, mobile measurements on the road and at a local animal farm (pigs, turkeys) in central New Jersey to measure vehicular and agricultural emissions. All field $\mathrm{NH}_{3}$ measurements are corrected for water vapor dilution and expressed as mixing ratios in dry air. Simultaneous measurements of a vehicle emission tracer carbon monoxide (CO) by a separate QClaser-based sensor (Tao et al., 2012b) were used to identify these emission sources. Figure 11a shows the time series of $\mathrm{NH}_{3}$ measurements at the animal farm. High mixing ratios above 1 ppmv $\mathrm{NH}_{3}$ are observed and do not correlate with $\mathrm{CO}$, which remained at near background mixing ratio at the animal farm. Figure $11 \mathrm{~b}$ illustrates on-road

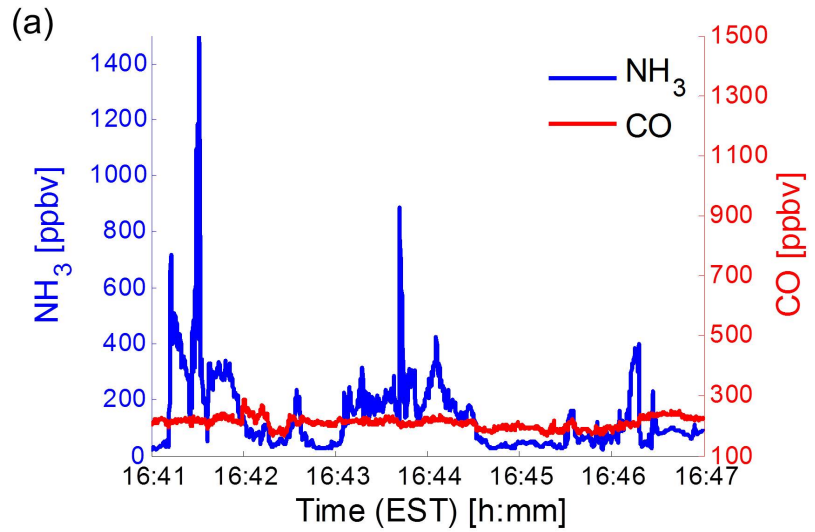

(b)

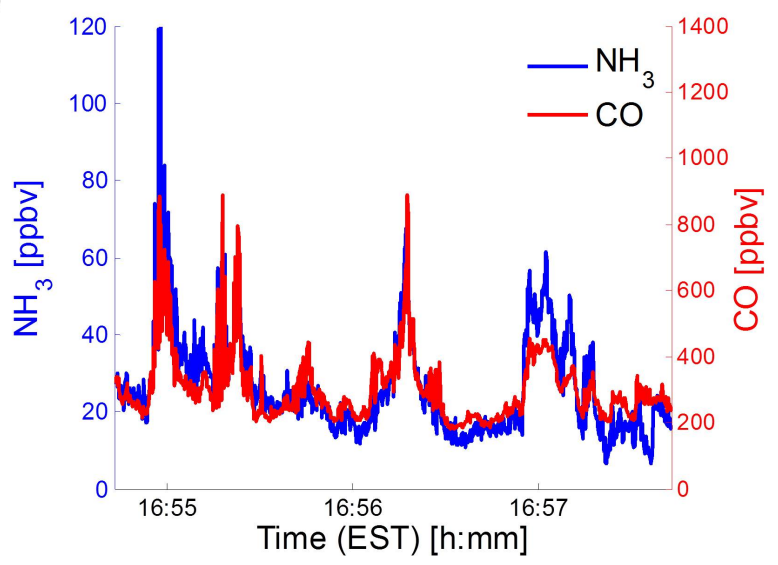

Fig. 11. (a) Time series of $\mathrm{NH}_{3}$ measurements at an animal farm in central New Jersey; (b) on-road measurements in the Princeton, New Jersey area, with transient spikes correlated with $\mathrm{CO}$ emissions from vehicles.

vehicle $\mathrm{NH}_{3}$ emission measurements, with maximum mixing ratios of $\sim 60-120 \mathrm{ppbv} \mathrm{NH}_{3}$, depending on vehicle type and driving conditions. The enhancements in $\mathrm{NH}_{3}$ mixing ratio (Fig. 11b) correlate with on-road $\mathrm{CO}$ measurements. These time series demonstrate the open-path $\mathrm{NH}_{3}$ sensor is capable of performing high time resolution field measurements to capture various emission sources.

The field measurements of $\mathrm{NH}_{3}$ and the nonadsorbing gas CO shown in Fig. 11b illustrate that there is no delay between the spikes of these two species, which occur on timescales of seconds, due to vehicle exhaust emissions. Other field measurements performed in tunnels (not shown here) indicate that open-path measurements of nonadsorbing gases, such as $\mathrm{CO}_{2}$, can serve as an indicator of true mixing ratio decay at the tunnel exit. Our open-path $\mathrm{NH}_{3}$ measurements show no delay compared with $\mathrm{CO}_{2}$ in this case. This further supports our conclusion that the surface adsorption time constant for our open-path $\mathrm{NH}_{3}$ measurement is significantly reduced at these measurement timescales compared with previous closed-path sensors. 


\section{Discussion}

The $\mathrm{NH}_{3}$ sensor noise-equivalent limit corresponds to a fractional absorption of $\sim 3 \times 10^{-5}$, comparable (within a factor of 3) with typical, field-deployable laser-based systems (Tittel et al., 2003). The detection limit and precision are limited by electrical noise and optical interference fringing, a dominant noise source in many laser absorption spectroscopy systems (Dharamsi et al., 1998; Werle, 2011). The dominant electrical noise sources are the power supplies used for the detector preamplifier and laser current driver. The dominant interference fringes in our system are due to the back reflections from transmissive optics (laser collimating lens and zinc selenide windows for laser, detector and reference cell packages) and QC laser beam quality for the multi-pass optical cell. Our current efforts focus on improving beam quality of the QC laser high heat load packages and optimizing transmissive optics with custom anti-reflective coatings. We note that the ultimate detection sensitivity is also constrained by other uncertainties, including the ability to isolate spectral interferences from $\mathrm{CO}_{2}$ and $\mathrm{O}_{3}$ absorption features near $9.06 \mu \mathrm{m}$ when approaching the $100 \mathrm{pptv}$ range.

The $2 \mathrm{f}$ signal baseline also affects calibration and zero offset measurements. This baseline is due to a combination of detector nonlinearity, intensity modulation and optical fringing. Further investigations on the long-term stability of this baseline under field conditions will be necessary to characterize the variability of the zero calibration and ultimately improve uncertainties at low mole fractions. This uncertainty is currently the most significant limitation for our openpath $\mathrm{NH}_{3}$ sensor. Signal baseline variability due to temperature changes is of particular concern for open-path systems, where the temperature cannot be controlled due to direct exposure of optical components and power limitations on field platforms.

The laser tuning capabilities also limit the desired sensitivity for open-path detection of the broad $\mathrm{NH}_{3}$ absorption feature. The optimal modulation index for $2 \mathrm{f}$ detection $(m=2.2$ as shown by Reid and Labrie, 1981) cannot be reached with the current QC laser used in our system due to limited current tuning range, which decreases with increasing modulation frequency (Tao et al., 2012a). We can only achieve a modulation index of $\sim 1.4$ for $\mathrm{NH}_{3}$ measurements. To address this issue, the integration of new QC lasers with twice the current tuning range is an ongoing effort.

Despite these limitations, we demonstrate a sensor platform capable of high-sensitivity, high time resolution atmospheric $\mathrm{NH}_{3}$ field measurements. Future autonomous field operation of this sensor for long-term stationary measurements will require further weather-proofing of the prototype sensor for protection from precipitation, dust and insects. These measures are particularly important for the optical cell mirrors, which must be directly exposed to environmental conditions.

\section{Summary}

We present the instrument performance of a compact, lowpower, field-deployable, open-path $\mathrm{NH}_{3}$ sensor. The system uses a QC laser at $9.06 \mu \mathrm{m}$, multi-pass Herriott cell, multiharmonic wavelength modulation spectroscopy and an inline ethylene reference cell. No cryogens are required due to the capabilities of TE-cooled, continuous-wave, distributedfeedback QC lasers and HgCdTe photodetectors. Our openpath $\mathrm{NH}_{3}$ sensor has the requisite capabilities for groundbased atmospheric measurements, with a precision and noise-equivalent limit of $0.15 \mathrm{ppbv} \mathrm{NH}_{3}$ at $10 \mathrm{~Hz}$ and total accuracy of $0.20 \mathrm{ppbv} \mathrm{NH}_{3} \pm 10 \%$. The sensor is capable of measuring a large dynamic range of $\mathrm{NH}_{3}$ mixing ratios due to in situ emission sources. The fast $(10 \mathrm{~Hz})$ time resolution of the open-path system can be used to capture transient $\mathrm{NH}_{3}$ sources with a short surface adsorption time constant. This is demonstrated by comparing the open-path $\mathrm{NH}_{3}$ sensor response with the simultaneous time response of collocated sensors measuring nonadsorbing species.

It is important to note that surface sampling artifacts in closed-path sensors are typically reduced by minimizing inlet length, optimizing inlet coatings, inlet heating and maintaining high flow rates through small sampling volumes or other special sampling systems (Whitehead et al., 2008; Bianchi et al., 2012). Some of these measures increase power demands and limit portability for a variety of field platforms. In contrast, our open-path approach is advantageous in that it has minimal sampling artifacts and does not require pumps or heaters, allowing for a lower-power, portable design.

The compact, low-power design provides unique capabilities for stationary sensing and mobile platform spatial mapping of $\mathrm{NH}_{3}$ mixing ratios. In addition, the open-path sensor precision, stability and time resolution $(10 \mathrm{~Hz})$ make it suitable for future eddy covariance $\mathrm{NH}_{3}$ flux measurements. Future investigations will focus on long-term intercomparisons with existing commercial, atmospheric $\mathrm{NH}_{3}$ sensors and demonstration of open-path eddy covariance $\mathrm{NH}_{3}$ flux measurements. Future measurement applications for this openpath sensor include $\mathrm{NH}_{3}$ emission measurements in agricultural and urban regions to validate emission inventories.

Acknowledgements. The authors would like to thank all those who have provided insights on the sensor development and field testing, including the research groups of Claire Gmachl, James Smith, Elie Bou-Zeid, Jennifer Murphy, Claire Welty, and Gerard Wysocki, as well as Minghui Diao, Josh DiGangi, Anthony O'Brien, Kristine Rafferty, Caitlyn Puzio, Oshane Mcrae and Brandon Parkes. We also gratefully acknowledge James Crawford, John Nowak and the DISCOVER-AQ SJV 2013 team, Trent Proctor (USFS), the NOAA CALNEX 2010 Bakersfield supersite team, Gordon Dey Farms and Joel Silver (Southwest Sciences, Inc.). This research is supported by the NSF Center for Mid-Infrared Technologies for Health and the Environment (MIRTHE, NSF-ERC) under grant no. EEC-0540832. D. J. Miller was supported by the National 
Science Foundation Graduate Research Fellowship under grant no. DGE-0646086. K. Sun is supported by NASA Earth and Space Science Fellowship IIP-1263579. We thank two anonymous reviewers and the editors, including the late Peter Werle, for helpful comments and suggestions to improve the manuscript.

Edited by: D. Griffith

\section{References}

Adams, P. J., Seinfeld, J. H., Koch, D., Mickley, L., and Jacob, D.: General circulation model assessment of direct radiative forcing by the sulfate-nitrate-ammonium-water inorganic aerosol system, J. Geophys. Res., 106, 1097-1111, 2001.

Anderson, N., Strader, R., and Davidson, C.: Airborne reduced nitrogen: ammonia emissions from agriculture and other sources, Environ. Int., 29, 277-286, 2003.

Aneja, V. P., Blunden, J., James, K., Schlesinger, W. H., Knighton, R., Gilliam, W., Jennings, G., Niyogi, D., and Cole, S.: Ammonia Assessment from Agriculture: U.S. Status and Needs, J. Environ. Qual., 37, 515-520, 2008.

Ball, S. M., Hanson, D. R., Eisele, F. L., and McMurry, P. H.: Laboratory studies of particle nucleation: Initial results for $\mathrm{H}_{2} \mathrm{SO}_{4}$, $\mathrm{H}_{2} \mathrm{O}$, and $\mathrm{NH}_{3}$ vapors, J. Geophys. Res., 104, 23709-23718, 1999.

Battye, W., Aneja, V. P., and Roelle, P. A.: Evaluation and improvement of ammonia emissions inventories, Atmos. Environ., 37, 3873-3883, 2003.

Benson, D. R., Markovich, A., Al-Refai, M., and Lee, S.-H.: A Chemical Ionization Mass Spectrometer for ambient measurements of Ammonia, Atmos. Meas. Tech., 3, 1075-1087, doi:10.5194/amt-3-1075-2010, 2010.

Benson, D. R., Yu, J. H., Markovich, A., and Lee, S.-H.: Ternary homogeneous nucleation of $\mathrm{H}_{2} \mathrm{SO}_{4}, \mathrm{NH}_{3}$, and $\mathrm{H}_{2} \mathrm{O}$ under conditions relevant to the lower troposphere, Atmos. Chem. Phys., 11, 4755-4766, doi:10.5194/acp-11-4755-2011, 2011.

Bianchi, F., Dommen, J., Mathot, S., and Baltensperger, U.: Online determination of ammonia at low pptv mixing ratios in the CLOUD chamber, Atmos. Meas. Tech., 5, 1719-1725, doi:10.5194/amt-5-1719-2012, 2012.

Bobbink, R., Hicks, K., Galloway, J., Spranger, T., Alkemade, R., Ashmore, M., Bustamante, M., Cinderby, S., Davidson, E., Dentener, F., Emmett, B., Erisman, J.-W., Fenn, M., Gilliam, F., Nordin, A., Pardo, L., and DeVries, W.: Global assessment of nitrogen deposition effects on terrestrial plant diversity: a synthesis, Ecol. App., 20, 30-59, 2010.

Claps, R., Englich, F. V., Leleux, D. P., Richter, D., Tittel, F. K., and Curl, R. F.: Ammonia Detection by use of Near-Infrared DiodeLaser-Based Overtone Spectroscopy, Appl. Optics, 40, 43874394, 2001.

Clarisse, L., Clerbaux, C., Dentener, F., Hurtmans, D., and Coheur, P.: Global ammonia distribution derived from infrared satellite observations, Nat. Geosci., 2, 479-483, 2009.

Curl, R. F., Capasso, F., Gmachl, C., Kosterev, A. A., McManus, B., Lewicki, R., Pusharsky, M., Wysocki, G., and Tittel, F. K.: Quantum cascade lasers in chemical physics, Chem. Phys. Lett., 487, 1-18, 2010.
Dharamsi, A. N., Shea, P. C., and Bullock, A. M.: Reduction of effects of Fabry-Perot fringing in wavelength modulation experiments, Appl. Phys. Lett., 72, 3118, doi:10.1063/1.121565, 1998.

Ellis, R. A., Murphy, J. G., Pattey, E., van Haarlem, R., O’Brien, J. M., and Herndon, S. C.: Characterizing a Quantum Cascade Tunable Infrared Laser Differential Absorption Spectrometer (QCTILDAS) for measurements of atmospheric ammonia, Atmos. Meas. Tech., 3, 397-406, doi:10.5194/amt-3-397-2010, 2010.

Ellis, R. A., Murphy, J. G., Markovic, M. Z., VandenBoer, T. C., Makar, P. A., Brook, J., and Mihele, C.: The influence of gasparticle partitioning and surface-atmosphere exchange on ammonia during BAQS-Met, Atmos. Chem. Phys., 11, 133-145, doi:10.5194/acp-11-133-2011, 2011.

Fehsenfeld, F. C., Huey, L. G., Leibrock, E., Dissly, R., Williams, E., Ryerson, T. B., Norton, R., Sueper, D. T., and Hartsell, B.: Results from an informal intercomparison of ammonia measurement techniques, J. Geophys. Res., 107, 4812, doi:10.1029/2001jd001327, 2002.

Galle, B., Bergquist, B., Ferm, M., T'ornquist, K., Griffith, D. W. T., Jensen, N. O., and Hansen, F.: Measurement of ammonia emissions from spreading of manure using gradient FTIR techniques, Atmos. Environ., 34, 4907-4915, 2000.

Galloway, J. N., Aber, J. D., Erisman, J. W., Seitzinger, S. P., Howarth, R. W., Cowling, E. B., and Cosby, B. J.: The Nitrogen Cascade, BioScience, 53, 341-356, 2003.

Gong, L., Lewicki, R., Griffin, R. J., Flynn, J. H., Lefer, B. L., and Tittel, F. K.: Atmospheric ammonia measurements in Houston, TX using an external-cavity quantum cascade laser-based sensor, Atmos. Chem. Phys., 11, 9721-9733, doi:10.5194/acp-11-97212011, 2011.

Griffith, D. W. T. and Galle, B.: Flux measurements of $\mathrm{NH}_{3}, \mathrm{~N}_{2} \mathrm{O}$ and $\mathrm{CO}_{2}$ using dual beam FTIR spectroscopy and the flux gradient technique, Atmos. Environ., 34, 1087-1098, 2000.

Hanson, D. R. and Eisele, F. L.: Measurement of pre-nucleation molecular clusters in the $\mathrm{NH}_{3}, \mathrm{H}_{2} \mathrm{SO}_{4}, \mathrm{H}_{2} \mathrm{O}$ system, J. Geophys. Res., 107, 4158, doi:10.1029/2001JD001100, 2002.

Heald, C. L., J. L. Collett Jr., Lee, T., Benedict, K. B., Schwandner, F. M., Li, Y., Clarisse, L., Hurtmans, D. R., Van Damme, M., Clerbaux, C., Coheur, P.-F., Philip, S., Martin, R. V., and Pye, H. O. T.: Atmospheric ammonia and particulate inorganic nitrogen over the United States, Atmos. Chem. Phys., 12, 10295-10312, doi:10.5194/acp-12-10295-2012, 2012.

Herriott, D., Kogelnik, H., and Kompfner, R.: Off-axis paths in spherical mirror interferometers, Appl. Optics, 3, 523-526, 1964.

Jimenez, J. L., Canagaratna, M. R., Donahue, N. M., Prevot, A. S. H., Zhang, Q., Kroll, J. H., DeCarlo, P. F., Allan, J. D., Coe, H., Ng, N. L., Aiken, A. C., Docherty, K. S., Ulbrich, I. M., Grieshop, A. P., Robinson, A. L., Duplissy, J., Smith, J. D., Wilson, K. R., Lanz, V. A., Hueglin, C., Sun, Y. L., Tian, J., Laaksonen, A., Raatikainen, T., Rautiainen, J., Vaattovaara, P., Ehn, M., Kulmala, M., Tomlinson, J. M., Collins, D. R., Cubison, M. J., Dunlea, E. J., Huffman, J. A., Onasch, T. B., Alfarra, M. R., Williams, P. I., Bower, K., Kondo, Y., Schneider, J., Drewnick, F., Borrmann, S., Weimer, S., Demerjian, K., Salcedo, D., Cottrell, L., Grif?n, R., Takami, A., Miyoshi, T., Hatakeyama, S., Shimono, A., Sun, J. Y., Zhang, Y. M., Dzepina, K., Kimmel, J. R., Sueper, D., Jayne, J. T., Herndon, S. C., Trimborn, A. M., Williams, L. R., Wood, E. C., Middlebrook, A. M., Kolb, C. E., Baltensperger, U., and Worsnop, D. R.: Evolution 
of organic aerosols in the atmosphere, Science, 326, 1525-1529, doi:10.1126/science.1180353, 2009.

Kosterev, A. A. and Tittel, F. K.: Ammonia Detection by Use of Quartz-Enhanced Photoacoustic Spectroscopy with a Near-IR Telecommunication Diode Laser, Appl. Optics, 43, 6213-6217, 2004.

Manne, J., Sukhorukov, O., Jager, W., and Tulip, J.: Pulsed quantum cascade laser-based cavity ring-down spectroscopy for ammonia detection in breath, Appl. Optics, 45, 9230-9237, 2006.

Manne, J., Jager, W., and Tulip, J.: Sensitive detection of ammonia and ethylene with a pulsed quantum cascade laser using intra and interpulse spectroscopic techniques, Appl. Phys. B, 94, 337-344, 2009.

Martin, S. T., Hung, H.-M., Park, R. J., Jacob, D. J., Spurr, R. J. D., Chance, K. V., and Chin, M.: Effects of the physical state of tropospheric ammonium-sulfate-nitrate particles on global aerosol direct radiative forcing, Atmos. Chem. Phys., 4, 183214, doi:10.5194/acp-4-183-2004, 2004.

McDermitt, D., Burba, G., Xu, L., Anderson, T., Komissarov, A., Riensche, B., Schedlbauer, J., Starr, G., Zona, D., Oechel, W., Oberbauer, S., and Hastings, S.: A new low-power, open-path instrument for measuring methane flux by eddy covariance, Appl. Phys. B, 102, 391-405, 2011.

McManus, J. B., Shorter, J. H., Nelson, D. D., Zahniser, M. S., Glenn, D. E., and Mcgovern, R. M.: Pulsed quantum cascade laser instrument with compact design for rapid, high sensitivity measurements of trace gases in air, Appl. Phys. B, 92, 387-392, 2008.

McMurry, P. H., Fink, M., Sakuri, H., Stolzenburg, M., Mauldin III, R. L., Smith, J., Eisele, F. L., Moore, K., Sjostedt, S., Tanner, D., Huey, L. G., Nowak, J. B., Edgerton, E., and Voisin, D.: A criterion for new particle formation in the sulfur-rich Atlanta atmosphere, J. Geophys. Res., 110, D22S02, doi:10.1029/2005JD005901, 2005.

Miller, D. J., Sun, K., Tao, L., Khan, M. A., and Zondlo, M. A.: Assessing field performance of an open-path quantum cascade laser sensor for measuring atmospheric ammonia, Conference on Laser Electro-Optics: Optical Society of America, San Jose, California, 6 May 2012, ATh3L.7, 2012.

Mount, G. H., Rumburg, B., Havig, J., Lamb, B., Westberg, H., Yonge, D., Johnson, K., and Kincaid, R.: Measurement of atmospheric ammonia at a dairy using differential optical absorption spectroscopy in the mid-ultraviolet, Atmos. Environ., 36, 17991810, 2002.

Nowak, J. B., Neuman, J. A., Kozai, K., Huey, L. G., Tanner, D. J., Holloway, J. S., Ryerson, T. B., Frost, G. J., McKeen, S. A., and Fehsenfeld, F. C.: A chemical ionization mass spectrometry technique for airborne measurements of ammonia, J. Geophys. Res., 112, D10S02, doi:10.1029/2006JD007589, 2007.

Nowak, J. B., Neuman, J. A., Bahreini, R., Middlebrook, A. M., Holloway, J. S., McKeen, S. A., Parrish, D. D., Ryerson, T. B., and Trainer, M.: Ammonia sources in the California South Coast Air Basin and their impact on ammonium nitrate formation, Geophys. Res. Lett., 39, L07804, doi:10.1029/2012GL051197, 2012.

Owen, K., Essebbar, E., and Farooq, A.: Measurements of $\mathrm{NH}_{3}$ linestrengths and collisional broadening coefficients in $\mathrm{N}_{2}, \mathrm{O}_{2}$, $\mathrm{CO}_{2}$, and $\mathrm{H}_{2} \mathrm{O}$ near $1103.46 \mathrm{~cm}^{-1}$, J. Quant. Spectrosc. Ra., 121, 56-68, 2013.
Peeters, R., Berden, G., Apituley, A., and Meijer, G.: Open-path trace gas detection of ammonia based on cavity-enhanced absorption spectroscopy, Appl. Phys. B, 71, 231-236, 2000.

Pinder, R. W., Gilliland, A. B., and Dennis, R. L.: Environmental impact of atmospheric $\mathrm{NH}_{3}$ emissions under present and future conditions in the eastern United States, Geophy. Res. Lett. 35, L12808, doi:10.1029/2008GL033732, 2008.

Reid, J. and Labrie, D.: Second-harmonic detection with tunable diode lasers - Comparison of experiment and theory, Appl. Phys. B., 26, 203-210, 1981.

Rothman, L. S., Gordon, I. E., Barbe, A., Benner, D. C., Bernath, P. F., Birk, M., Boudon, V., Brown, L. R., Campargue, A., Champion, J. P., Chance, K., Coudert, L. H., Dana, V., Devi, V. M., Fally, S., Flaud, J. M., Gamache, R. R., Goldman, A., Jacquemart, D., Kleiner, I., Lacome, N., Lafferty, W. J., Mandin, J. Y., Massie, S. T., Mikhailenko, S. N., Miller, C. E., Moazzen-Ahmadi, N., Naumenko, O. V., Nikitin, A. V., Orphal, J., Perevalov, V. I., Perrin, A., Predoi-Cross, A., Rinsland, C. P., Rotger, M., Šimečková, M., Smith, M. A. H., Sun, K., Tashkun, S. A., Tennyson, J., Toth, R. A., Vandaele, A. C., and Vander Auwera, J.: The HITRAN 2008 molecular spectroscopic database, J. Quant. Spectrosc. Ra., 110, 533-572, 2009.

Schilt, S., Thévenaz, L., and Robert, P.: Wavelength modulation spectroscopy: combined frequency and intensity laser modulation, Appl. Optics, 42, 6728-6738, 2003.

Sintermann, J., Spirig, C., Jordan, A., Kuhn, U., Ammann, C., and Neftel, A.: Eddy covariance flux measurements of ammonia by high temperature chemical ionisation mass spectrometry, Atmos. Meas. Tech., 4, 599-616, doi:10.5194/amt-4-599-2011, 2011.

Solomon, S., Qin, D., Manning, M., Chen, Z., Marquis, M., Avery, K. B., Tignor, M., and Miller, H. L. (Eds.): IPCC, 2007: Climate Change 2007: The Physical Science Basis. Contribution of Working Group I to the Fourth Assessment Report of the Intergovernmental Panel on Climate Change, Cambridge University Press, Cambridge, United Kingdom and New York, NY, USA, 2007.

Sun, K., Tao, L., Miller, D. J., Khan, M. A., and Zondlo, M. A.: Inline Multi-harmonic Calibration Method for Open-path Atmospheric Ammonia Measurements, Appl. Phys. B, 110, 213-222, 2013.

Tabazadeh, A. and Toon, O. B.: The role of ammoniated aerosols in cirrus cloud nucleation, Geophys. Res. Lett., 25, 1379-1382, 1998.

Tao, L., Sun, K., Miller, D. J., Khan, M. A., and Zondlo, M. A.: Current and frequency modulation characteristics for continuouswave quantum cascade lasers at $9.06 \mu \mathrm{m}$, Opt. Lett., 37, 13581360, 2012a.

Tao, L., Sun, K., Khan, M. A., Miller, D. J., and Zondlo, M. A.: Compact and portable open-path sensor for simultaneous measurements of atmospheric $\mathrm{N}_{2} \mathrm{O}$ and $\mathrm{CO}$ using a quantum cascade laser, Opt. Express, 20, 28106-28118, 2012b.

Thoma, E. D., Shores, R. C., Thompson, E. L., Harris, D. B., Thorneloe, S. A., Varma, R. M., Hashmonay, R. A., Modrak, M. T., Natschke D. F., and Gamble, H. A.: Open-Path Tunable Diode Laser Absorption Spectroscopy for Acquisition of Fugitive Emission Flux Data, J. Air Waste Manage., 55, 658-668, 2005.

Tittel, F. K., Richter, D., and Fried, A.: Mid-infrared laser applications in spectroscopy, Top. Appl. Phys., 89, 445-510, 2003. 
Volten, H., Bergwerff, J. B., Haaima, M., Lolkema, D. E., Berkhout, A. J. C., van der Hoff, G. R., Potma, C. J. M., Wichink Kruit, R. J., van Pul, W. A. J., and Swart, D. P. J.: Two instruments based on differential optical absorption spectroscopy (DOAS) to measure accurate ammonia concentrations in the atmosphere, Atmos. Meas. Tech., 5, 413-427, doi:10.5194/amt-5-413-2012, 2012.

von Bobrutzki, K., Braban, C. F., Famulari, D., Jones, S. K., Blackall, T., Smith, T. E. L., Blom, M., Coe, H., Gallagher, M., Ghalaieny, M., McGillen, M. R., Percival, C. J., Whitehead, J. D., Ellis, R., Murphy, J., Mohacsi, A., Pogany, A., Junninen, H., Rantanen, S., Sutton, M. A., and Nemitz, E.: Field inter-comparison of eleven atmospheric ammonia measurement techniques, Atmos. Meas. Tech., 3, 91-112, doi:10.5194/amt-3-91-2010, 2010.

Walker, J. M., Philip, S., Martin, R. V., and Seinfeld, J. H.: Simulation of nitrate, sulfate, and ammonium aerosols over the United States, Atmos. Chem. Phys., 12, 11213-11227, doi:10.5194/acp12-11213-2012, 2012.

Wang, J., Hoffmann, A. A., Park, R. J., Jacob, D. J., and Martin, S. T.: Global distribution of solid and aqueous sulfate aerosols: Effect of the hysteresis of particle phase transitions, J. Geophys. Res., 113, D11206, doi:10.1029/2007jd009367, 2008.

Werle, P.: Accuracy and precision of laser spectrometers for trace gas sensing in the presence of optical fringes and atmospheric turbulence, Appl. Phys. B, 102, 313-329, 2011.
Werle, P., Mücke, R., and Slemr, F.: The limits of signal averaging in atmospheric trace-gas monitoring by tunable diode-laser absorption spectroscopy (TDLAS), Appl. Phys. B, 57, 131-139, 1993.

Whitehead, J. D., Longley, I. D., and Gallagher, M. W.: Seasonal and Diurnal Variation in Atmospheric Ammonia in an Urban Environment Measured Using a Quantum Cascade Laser Absorption Spectrometer, Water Air Soil Poll., 183, 317-329, 2007.

Whitehead, J. D., Twigg, M., Famulari, D., Nemitz, E., Sutton, M. A., Gallagher, M. W., and Fowler, D.: Evaluation of Laser Absorption Spectroscopic Techniques for Eddy Covariance Flux Measurements of Ammonia, Environ. Sci. Technol., 42, 20412046, 2008.

Yokelson, R. J., Christian, T. J., Bertschi, I. T., and Hao, W. M.: Evaluation of adsorption effects on measurements of ammonia, acetic acid, and methanol, J. Geophys. Res., 108, D204649, doi:10.1029/2003JD003549, 2003.

Zondlo, M. A., Paige, M. E., Massick, S. M., and Silver, J. A.: Vertical cavity laser hygrometer for the National Science Foundation Gulfstream V aircraft, J. Geophys. Res., 115, D20309, doi:10.1029/2010JD014445, 2010. 